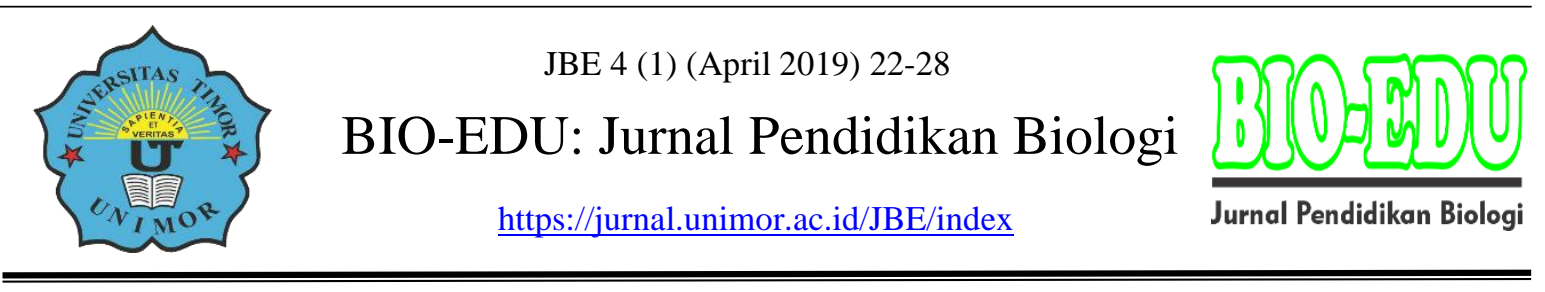

\title{
Pengaruh Pemberian Air Kelapa terhadap Perkembangan Embrio pada Dendrobium anosmum Lindl.
}

\author{
Ni Putu Yuni Astriani Dewi \\ Program Studi Magister Biologi Program Pascasarjana,Udayana University \\ Jl. P.B Sudirman, Denpasar-Bali 80232 \\ Email: yuniastriani@ymail.com
}

DOI: https://doi.org/10.32938/jbe.v4i1.343

\begin{abstract}
Abstrak
Penelitian ini bertujuan untuk mengetahui pengaruh penambahan air kelapa pada media kultur terhadap jumlah embrio pada D. anosmum Lindl.. Penelitian dilakukan di Laboratorium Struktur dan Perkembangan Tumbuhan, Jurusan Biologi, Fakultas Matematika dan Ilmu Pengetahuan Alam Universitas Udayana dan di UPT. Balai Benih Induk Tanaman Pangan dan Hortikultura Provinsi Bali pada Bulan Februari 2015 hingga Juli 2015. Tiga macam media dasar digunakan yaitu PDA, Organik, dan MS dengan tiga konsentrasi air kelapa sebanyak 0 $\mathrm{ml} / \mathrm{L}, 50 \mathrm{ml} / \mathrm{L}$ dan $100 \mathrm{ml} / \mathrm{L}$. Hasil penelitian menunjukkan bahwa penambahan air kelapa sebanyak $100 \mathrm{ml} / \mathrm{L}$ pada MS menunjukkan bahwa media tersebut mampu meningkatkan jumlah embrio tahap akhir yang terbentuk (> $32 \mathrm{sel})$.
\end{abstract}

Kata kunci: Kultur Jaringan, Anggrek, Perkecambahan, Murashige and Skoog, Perkembangan Embrio, dan Proembrio.

Abstract
The aim of the research is to find out effect of addition of coconut water in the media to the number of last stage D. anosmum Lindl embryo. Research was conducted at the Plant Structure and Development of Laboratory, Department of Biology, Faculty of Mathematics and Natural Sciences University of Udayana and UPT. Balai Benih Induk Tanaman Pangan dan Hortikultura Provinsi Bali from February 2015 to July 2015. Three type of media were employed, i.e. PDA, Organic, MS. Three different concentration of coconut was added to media, i.e. $0 \mathrm{ml} / \mathrm{L} 50 \mathrm{ml} / \mathrm{L}, 100 \mathrm{ml} / \mathrm{L}$. Results showed that addition of $100 \mathrm{ml} / \mathrm{L}$ coconut water in MS showed that media is capable to increase the formation of final stages embryos (> 32 cells).

Keywords: Tissue Culture, Orchid, Germination, Murashige and Skoog, Embryo Growth, and Proembryo.

\section{PENDAHULUAN}

Beberapa jenis anggrek mengalami penurunan populasi yang disebabkan adanya eksploitasi anggrek yang tidak terkontrol, kerusakan habitat akibat kebakaran hutan dan tanah longsor (Lisnandar dkk., 2012). Pemanfaatan kawasan untuk pembukaan jalan baru di habitat aslinya juga merupakan salah satu penyebab populasi termasuk anggrek $D$. anosmum Lindl. semakin menurun.

22 | D e w i / B E 4 ( 1) (April 2019) 22 - 28 
Dendrobium anosmum Lindl. merupakan salah satu anggrek epifit yang tumbuh secara alami di daratan Asia yaitu Thailand, India, Sri Lanka, Laos, Vietnam, Filipina, Malaysia, Indonesia, dan Papua New Guinea (Tuhuteru dkk., 2012). D. anosmum Lindl. dapat dijumpai di Indonesia seperti kawasan hutan tropis di Pegunungan Wilis dan Lereng Lawu Selatan (Yulia, 2010).

Kegiatan perbanyakan $D$. anosmum Lindl. menjadi sangat penting dilakukan mengingat kondisi habitatnya yang sudah tidak lagi mendukung kehidupan anggrek ini. Salah satu upaya dalam melakukan konservasi terhadap D. anosmum Lindl. adalah dengan melakukan perbanyakan secara massal di laboratorium (konservasi ex-situ). Konservasi exsitu pada $D$. anosmum Lindl. dapat dilakukan dengan menggunakan teknik kultur jaringan.

Pada teknik kultur jaringan penggunaan zat pengatur tumbuh memiliki peranan penting dalam pertumbuhan dan perkembangan tanaman, seperti pembesaran sel, pada aktivitas sel kambium, pertumbuhan akar, pada pembentukan tunas adventif, dan proliferasi tunas aksilar, serta pembentukan akar (Pramanik dan Rachmawati, 2010). Salah satu bahan alami yang dapat digunakan sebagai zat pengatur tumbuh adalah air kelapa.

Penggunaan air kelapa sebagai bahan organik merupakan salah satu cara untuk menggantikan penggunaan bahan sintetis yang dipakai dalam pembuatan media kultur, seperti Kinetin. Kelapa yang digunakan adalah kelapa yang berumur 7-8 bulan ( \pm 210 hari) (Kristina dan Sitti, 2012). Tuhuteru dkk. (2012) telah melakukan penelitian dari eksplan $D$. anosmum Lindl. yang memiliki tinggi $2-4 \mathrm{~cm}$.

Udomdee et al. (2014) telah melakukan penelitian mengenai perkecambahan benih Dendrobium nobile dari hasil silangan dengan menggunakan media dasar Murashige and Skoog (MS) dan konsentrasi gula yang berbeda. Hasil penelitian menunjukkan bahwa media MS dengan konsentrasi gula $10 \mathrm{~g} / \mathrm{L}$ mampu memacu perkecambahan secara optimal.

Penelitian ini menggunakan tiga media yaitu media PDA, Organik, dan MS dengan penambahan air kelapa sebagai zat pengatur tumbuh untuk mengetahui pertumbuhan benih anggrek D. anosmum Lindl. sebagai upaya dalam melakukan konservasi terhadap anggrek spesies di Indonesia.

\section{METODE}

Penelitian ini dimulai dari Bulan Februari 2015 hingga Bulan Juli 2015 di Laboratorium Kultur Jaringan Anggrek UPT. Balai Benih Induk Tanaman Pangan dan Hortikultura Desa Luwus, Kecamatan Baturiti, Kabupaten Tabanan Provinsi Bali dan di Laboratorium Struktur dan Perkembangan Tumbuhan Fakultas Matematika dan Ilmu Pengetahuan Alam, Universitas Udayana. Sampel buah anggrek diambil dari Kebun Raya Eka Karya Bali.

\section{Bahan Penelitian}

Bahan yang digunakan pada penelitian ini adalah buah anggrek $D$. anosmum Lindl. yang berumur 5 bulan. Bahan-bahan yang digunakan pada kultur benih anggrek yaitu agar, pisang ambon, gula pasir, air kelapa, kentang, tomat, media MS, dan media organik. 


\section{Persiapan Air Kelapa}

Air kelapa yang digunakan diambil dari buah kelapa yang daging buahnya tidak terlalu lunak, tetapi juga belum terlalu keras (umur 210-240 hari). Air kelapa disaring dan selanjutnya dipanaskan hingga mendidih, lalu digunakan dalam pembuatan media (air kelapa ditambahkan saat media dipanaskan) (Tuhuteru dkk., 2012).

\section{Bahan-bahan Media Organik}

Media organik menggunakan bahan-bahan seperti gula (20 gr/L), agar ( $8 \mathrm{gr} / \mathrm{L})$, arang (2 gr/L), vitamin C (100 mg/L), pisang ambon (150 gr/L), sari kentang ( $250 \mathrm{ml} / \mathrm{L})$, Gandasil (4 gr/L) (Shintiavira dkk., 2014), aquadest, $\mathrm{HCl}$, dan air kelapa.

\section{Bahan-bahan Media Potato Dextrose Agar (PDA)}

Media PDA menggunakan bahan-bahan seperti gula (20 gr/L), agar (8 gr/L), fish emulsion ( $3 \mathrm{ml} / \mathrm{L})$, sari kentang $(250 \mathrm{ml} / \mathrm{L})$, Gandasil (4 gr/L) (Shintiavira dkk., 2014), aquadest, $\mathrm{HCl}$, dan air kelapa.

\section{Bahan-bahan Media Murashige and Skoog (MS)}

Media MS menggunakan bahan-bahan seperti media MS instan (4,43 gr/L), gula (20 $\mathrm{gr} / \mathrm{L})$, agar (8 gr/L), tomat (100 g/L), aquadest, $\mathrm{HCl}$, dan air kelapa.

\section{Sterilisasi Kapsul Dendrobium Anosmum Lindl.}

Kapsul anggrek disterilkan terlebih dahulu dengan merendam kapsul ke dalam alkohol 70\% selama 3 menit dan 0,6\% Sodium hypochlorite selama 10 menit. Kemudian kapsul di cuci bersih dengan air steril sebanyak 3 kali lalu dimasukkan ke dalam alkohol 95\% selama 15 detik dan dipanaskan dengan api bunsen selama 2-3 detik (Udomdee et al., 2014).

Penelitian ini menggunakan Rancangan Acak Lengkap Faktorial dengan 2 faktor. Faktor pertama adalah zat pengatur tumbuh air kelapa yang terdiri dari 3 konsentrasi yaitu 0 (kontrol), $50 \mathrm{ml} / \mathrm{L}$, dan $100 \mathrm{ml} / \mathrm{L}$. Faktor kedua adalah media yang terdiri dari 3 macam media yaitu media organik, PDA, dan MS. Diperoleh 9 kombinasi perlakuan dan masingmasing kombinasi perlakuan diulang sebanyak 4 kali sehingga terdapat 36 unit percobaan (Tabel 1).

Tabel 1. Kombinasi Perlakuan Air Kelapa dan Media Kultur pada Benih Anggrek $D$. anosmum Lindl.

\begin{tabular}{|c|c|c|c|c|}
\hline \multirow{2}{*}{\multicolumn{2}{|c|}{$\begin{array}{ll}F 2 & F 1 \\
\end{array}$}} & \multicolumn{3}{|c|}{ Media Kultur } \\
\hline & & Mo & MS & PDA \\
\hline \multirow{3}{*}{$\begin{array}{c}\text { Air } \\
\text { kelapa }\end{array}$} & & U & & \\
\hline & & & & \\
\hline & (K2 & MoK2 & MSK2 & PD \\
\hline
\end{tabular}

Keterangan :

$\mathrm{F} 1=$ Faktor pertama, $\mathrm{F} 2=$ Faktor kedua, $\mathrm{K} 0=$ Perlakuan kontrol, $\mathrm{K} 1=$ Perlakuan dengan pemberian $50 \mathrm{ml} / \mathrm{L}$ air kelapa ke masing-masing media, $\mathrm{K} 2=$ Perlakuan dengan pemberian 
$100 \mathrm{ml} / \mathrm{L}$ air kelapa ke masing-masing media, Mo = Media organik, MS = Murashige and Skoog, PDA = Potato Dextrose Agar

\section{Analisis Data}

Data kuantitatif yang diperoleh pada penelitian ini dianalisis dengan analisis sidik ragam atau ANOVA (Analysis of Variance) dengan menggunakan software SPSS for Windows pada taraf nyata $(\alpha)<0,05$. Uji akan dilanjutkan dengan uji Duncan dengan bantuan SPSS versi 16.0 for Windows (Priyatno 2012).

\section{HASIL DAN PEMBAHASAN}

\section{Hasil}

Pengaruh Penambahan Air Kelapa dengan Konsentrasi yang Berbeda pada Media PDA, Organik dan MS Terhadap Jumlah Embrio D. anosmum Lindl Tahap Akhir yang Terbentuk ( $\geq 32$ sel).

Hasil uji ANOVA menunjukkan bahwa pengaruh penambahan air kelapa berbeda nyata pada tiga media terhadap jumlah embrio tahap akhir yang terbentuk. Penambahan air kelapa berpengaruh nyata terhadap jumlah embrio tahap akhir yang terbentuk. Hal ini dapat dilihat dari F hitung lebih besar dari 0,05. Hasil penelitian menunjukkan jumlah embrio tahap akhir tertinggi pada penambahan air kelapa sebanyak $100 \mathrm{ml} / \mathrm{L}$ pada media MS berpengaruh terhadap jumlah embrio tahap akhir yang terbentuk yaitu embrio tahap $\geq 32$ sel (Tabel 2).

Tabel 2. Pengaruh Penambahan Air Kelapa pada Tiga Media terhadap Jumlah Embrio Tahap Akhir ( $\geq 32$ sel ) yang Terbentuk pada 12 MST

\begin{tabular}{clc}
\hline No. & Perlakuan & $\begin{array}{c}\text { Jumlah } \\
\text { embrio } \\
\text { tahap akhir }\end{array}$ \\
\hline 1. & Kontrol & $0,37 \mathrm{a}$ \\
2. & PDK0 & $5,37 \mathrm{~b}$ \\
3. & PDK1 & $8,33 \mathrm{bc}$ \\
4. & PDK2 & $6,73 \mathrm{~b}$ \\
5. & MOK0 & $8,57 \mathrm{bc}$ \\
6. & MOK1 & $8,87 \mathrm{bc}$ \\
7. & MOK2 & $9,00 \mathrm{bc}$ \\
8. & MSK0 & $11,57 \mathrm{c}$ \\
9. & MSK1 & $20,70 \mathrm{~d}$ \\
10. & MSK2 & $24,40 \mathrm{e}$ \\
\hline
\end{tabular}

Keterangan : Kontrol $=$ Sebelum ditanam dalam media kultur, $\mathrm{K} 0=$ Perlakuan kontrol, $\mathrm{K} 1=$ Perlakuan dengan pemberian $50 \mathrm{ml} / \mathrm{L}$ air kelapa ke masing-masing media, K2 = Perlakuan dengan pemberian $100 \mathrm{ml} / \mathrm{L}$ air kelapa ke masing-masing media, Mo $=$ Media organik, MS = Murashige and Skoog, $\mathrm{PDA}=$ Potato Dextrose Agar 


\section{Pembahasan}

Pengaruh Penambahan Air Kelapa dengan Konsentrasi yang Berbeda pada Media PDA, Organik dan MS Terhadap Jumlah Embrio D. anosmum Lindl $\geq 32$ sel yang Terbentuk

Pengaruh penambahan air kelapa dengan konsentrasi $50 \mathrm{ml} / \mathrm{L}$ dan $100 \mathrm{ml} / \mathrm{L}$ pada media PDA, Organik dan MS terhadap perkecambahan benih $D$. anosmum Lindl. tidak terlihat. Hal ini dapat dilihat dengan tidak terbentuknya kalus pada media kultur. Namun pengamatan secara mikroskopis dari preparat Biji D. anosmum Lindl. yang sudah ditanam, melalui hasil ANOVA bahwa kontrol dengan penambahan air kelapa dengan konsentrasi berbeda pada masing-masing media Organik dan MS berpengaruh nyata terhadap jumlah embrio $\geq 32$ sel yang ditemui. Pada umur 12 MST di masing-masing perlakuan media terutama media PDA dan organik dengan penambahan air kelapa masih sedikit ditemukan embrio tahap akhir sedangkan jumlah embrio $\geq 32$ sel lebih banyak ditemui pada media MS dengan penambahan air kelapa sebanyak $50 \mathrm{ml} / \mathrm{L}$ dan $100 \mathrm{ml} / \mathrm{L}$.

Air kelapa baik digunakan pada media kultur jaringan karena mengandung zat atau bahan-bahan seperti vitamin, mineral, asam amino dan asam nukleat, fosfor serta zat tumbuh auksin dan giberelin yang berfungsi sebagai stimulator proliferasi jaringan, memperlancar metabolisme dan respirasi (Sari et al., (2011) ; (Husain, 2012). Menurut Semiarti et al. (2010), air kelapa dapat digunakan sebagai pengganti hormon sitokinin. Pada tingkat konsentrasi tertentu air kelapa dapat menginisiasi terbentuknya tunas. Penambahan air kelapa dengan konsentrasi $100 \mathrm{ml} / \mathrm{L}$ adalah efektif meningkatkan jumlah embrio $\geq 32$ sel. Hal ini dilihat dari jumlah embrio $\geq 32$ sel pada media MS 12 MST apabila dibandingkan dengan media PDA dan Organik yang ditambahkan air kelapa. Ini diduga karena kandungan sitokinin dalam media perlakuan dengan konsentrasi tersebut lebih tinggi sehingga memperlihatkan adanya pembelahan sel.

Air kelapa dengan konsentrasi $100 \mathrm{ml} / \mathrm{L}$ dalam media MS merupakan konsentrasi optimal dalam menghasilkan jumlah embrio $\geq 32$ sel yang terbentuk. Hal ini didukung oleh penelitian Tuhuteru et al. (2012), di dalam air kelapa terdapat kandungan sitokinin sehingga proses pembelahan sel terjadi secara terus menerus. Dapat dikatakan bahwa kandungan sitokinin dalam air kelapa dalam konsentrasi $100 \mathrm{ml} / \mathrm{L}$ tersebut mempengaruhi asam nukleat sehingga berpengaruh terhadap sintesa protein dan pengatur aktivitas enzim dalam hal pembelahan sel pada embrio $D$. anosmum Lindl.

Dalam media perlakuan, juga adanya media organik yang ditambahkan arang aktif atau charcoal. Walaupun penelitian ini jumlah embrio $\geq 32$ sel yang terbentuk hanya sedikit dijumpai dalam Media Organik, namun arang yang ditambahkan dalam Media Organik ini berguna untuk menyerap racun atau senyawa inhibitor yang disekresikan oleh plantlet ke dalam media. Disamping itu, arang aktif dapat mengurangi pencoklatan media akibat pemanasan tinggi setelah sterilisasi (Vogel et al., 2011).

Menurut Chyuam-Yih et al. (2011), penambahan arang aktif proanalis sebanyak 2 $\mathrm{g} / \mathrm{L}$ ke dalam media kultur dapat meningkatkan pertumbuhan benih. Namun demikian, semua bahan-bahan nutrisi baik yang berasal dari senyawa anorganik maupun senyawa organik tersebut, tingkat penyerapannya oleh bahan tanaman sangat dipengaruhi oleh $\mathrm{pH}$ media itu sendiri. Untuk pertumbuhan, $\mathrm{pH}$ yang sesuai adalah 5.0-6.5 sedangkan bila $\mathrm{pH}$ terlalu tinggi 
(>7.0) dapat menghambat atau bahkan menghentikan pertumbuhan dan perkembangan kultur secara in vitro (Vogel et al., 2011).

Dalam penelitian juga menggunakan media sederhana yaitu Potato Dextrose Agarl PDA. Walaupun hasil penelitian dengan menggunakan media PDA tidak menunjukkan perubahan pada jumlah embrio $\geq 32 \mathrm{sel} D$. anosmum Lindl. namun benih pada media tersebut tidak mengalami kematian. Menurut Widiastoety (2001), di dalam media kultur jaringan, bahan organik merupakan salah satu faktor penting pada media dikarenakan setiap bahanbahan organik terdapat sumber-sumber zat pengatur tumbuh, asam nukleat, asam amino serta serta unsur hara tambahan yang diduga diperlukan oleh tanaman baik dalam pertumbuhan maupun perkembangan tanaman tersebut.

Pertumbuhan dan perkembangan embrio $\geq 32$ sel yang terbentuk pada media MS lebih baik secara kualitatif jika dibandingkan dengan kedua media lain yakni PDA dan Organik. Hal ini dapat disebabkan karena kandungan unsur hara makro dan mikro pada media ini lebih kompleks jika dibandingkan dengan media lainnya. Menurut Chyuam-Yih et al. (2011), media MS adalah media yang kaya akan unsur nitrogen dalam proses pembelahan dan pembesaran sel maupun penyusunan asam amino.

\section{KESIMPULAN}

\section{Kesimpulan}

Dari penelitian ini dapat disimpulkan bahwa : Benih D. anosmum Lindl. pada media PDA, Organik dan MS tidak menunjukan terjadinya perkecambahan. Penambahan air kelapa sebanyak $100 \mathrm{ml} / \mathrm{L}$ pada media MS mampu meningkatkan jumlah embrio tahap akhir yang terbentuk ( $\geq 32 \mathrm{sel})$.

\section{DAFTAR RUJUKAN}

Chyuam-Yih Ng., Norihan Mohd. Saleh. 2011. In vitro propagation of Paphiopedilum orchid through formation of protocorm-like bodies. Plant Cell Tiss Organ Cult. 105:193202.

Husain, I., 2012. Induksi Protocorm pada Eksplan Bawang Putih pada Media MS Minim Hara Makro dan Mikro yang Ditambahkan Air Kelapa. JATT Vol. 1 No. 1. Hal: 31

Kristina, N. N dan Sitti, F.S. 2012. Pengaruh Air Kelapa Terhadap Multiplikasi Tunas In Vitro, Produksi Rimpang, Dan Kandungan Xanthorrhizol Temulawak Di Lapangan. Bogor : Jurnal Littri 18 (3) : 125-134.

Lisnandar, D. S., Widya M., Ari P. 2012. Pengaruh pemberian variasi konsentrasi NAA ( $\alpha$ naphthaleneacetic acid) dan $2.4 \mathrm{D}$ terhadap induksi protocorm like bodies (PLB) anggrek macan (Grammatophyllum scriptum (Lindl.). Surakarta : Bioteknologi 9 (2): 66-72.

Pramanik, D., Rachmawati, F. 2010. Pengaruh Jenis Media Kultur In Vitro dan Jenis eksplan terhadap Morfogenesis Lili Oriental. Cianjur : J. Hort. 20 (2) : 111-119.

Priyatno, D. 2012. Cara Kilat Belajar Analisis Data dengan SPSS 20. Cetakan Kedua. Yogyakarta : Andi.

27 | Dewi/JB 4(1) (April2 2019 ) 22-28 
Sari, Y.P., H. Manurung, Aspiah. 2011. Pengaruh Peberian Air Kelapa Terhadap Pertumbuhan Anggrek Kantog Semar (Paphiopedilum supardii Braem \& Loeb) Pada Media Knudson Secara In Vitro. Mulawarman Scientifie 10 (2). ISSN 1412 - 498X

Semiarti, E., Ari, Indrianto., Eko, A. S., Rizqie, L. N., Ratih, R. 2010. Mikropropagasi Tanaman Anggrek Hitam Coelogyne pandurata Lindl. Dengan Penyisipan Gen Penumbuh Tunas Melalui Agrobacterium. Yogyakarta : Seminar Nasional Biologi 2010.

Shintiavira., Rahmawati, H., I., Winarto, B. 2014. Aplikasi Modifikasi Media Generik Dalam Produksi Bibit Krisan (Dendranthema grandiflora Tzvelev) Berkualitas Melalui Kultur In Vitro. Cianjur: J. Hort. 24(3):220-229.

Tuhuteru, S., Hehanussa, M. L., Raharjo, S.H.T. 2012. Pertumbuhan Dan Perkembangan Anggrek Dendrobium anosmum Pada Media Kultur In Vitro Dengan Beberapa Konsentrasi Air Kelapa. Agrologia, 1(1) : 1-12.

Udomdee, W., Pei-Jung, W., Chen-Yu, L., Shih-Wen, C., Fure-Chyi, C. 2014. Effect of Sucrose Concentration and Seed Maturity on In vitro Germination of Dendrobium nobile hybrids. Plant Growth Regul 72 : 249-255.

Vogel, Ingrid N. Andrea, F. Macedo. 2011. Influence of IAA, TDZ, and light quality on asymbiotic germination, protocorm formation, and plantlet development of Cyrtopodium glutiniferum Raddi., medicinal orchid. Brazil : Plant Cell Tiss Organ Cult 104:147-155.

Yulia, N.D. 2010. Evaluasi Keragaman Anggrek Kawasan Hutan Alam Jawa Timur Bagian Selatan. Purwodadi : Kementerian Riset dan Teknologi Republik Indonesia dan Lembaga Ilmu Pengetahuan Indonesia. 